\title{
Comparison of Antibacterial Effects of Pulp Capping Materials
}

\author{
Elif Pınar Bakır(0000-0001-7564-4757) ${ }^{\alpha}$, Şeyhmus Bakır(0000-0003-2048-3065) ${ }^{\alpha}$, Samican Ünal(0000-0002-6486-1008) ${ }^{\alpha}$
}

Selcuk Dent J, 2021; 8: 553-560 (Doi: 10.15311/selcukdentj.896007)

Basvuru Tarihi: 12 Mart 2021 Yayına Kabul Tarihi: 24 Mayıs 2021

\section{ABSTRACT}

\section{Comparison of Antibacterial Effects of Pulp Capping Materials}

Background: The aim of this study is to evaluate the antibacterial effects of six different pulp capping materials on Streptococcus mutans, Lactobacillus acidophilus and Enterococcus faecalis bacteria in different time periods.

Methods: In our study, the antibacterial effects of TheraCal LC (BISCO Inc., USA), Dycal (Dentsply Tulsa Dental, USA), Biodentine (Septodont, France), Calcimol LC (Voco GmbH, Germany), Activa (Pulpdent Corporation, USA) and MTA Angelus (Angelus, Brazil) were tested against strains of S. mutans (ATCC 25175), L. acidophilus (RSKK 03037) and E. faecalis (ATCC 29212) using the disk diffusion method. Each of the materials was hardened in standard, $5 \mathrm{~mm}$ diameter, hollow sterile discs prepared beforehand in line with the manufacturer's recommendations. The materials extracted from the discs were placed in sterile sample containers. The materials placed in the sample containers were disinfected under UV light device for 20 minutes. The materials were placed in petri dishes containing the study isolates that were inoculated into the media at $2.5-3 \mathrm{~cm}$ intervals and homogeneously distributed. The same procedures were repeated for each microorganism in 10 separate petri dishes. The inhibition zone diameters around the discs that were left to incubate for $24-48$ hours at $37^{\circ} \mathrm{C}$ were measured in millimeters. Statistical analysis of the data was performed using one-way analysis of variance (One Way ANOVA), KolmogorovSmirnow, Levene tests and Bonferroni tests.

Results: At the end of the study, the tested materials showed a statistically significant antibacterial effect on all bacterial strains used $(p<0.05)$. MTA Angelus material showed the highest effect on all three bacterial groups compared to other pulp capping materials. Calcimol LC agent had the greatest effect on L. acidophilus, while other agents used in the study showed the greatest effect on S. mutans. The antibacterial effect of all pulp capping materials used in the study was found to be higher at the end of the 48th hour than at the end of the 24th hour, but there was no statistically significant difference $(p>0.05)$.

Conclusion: We think that the antibacterial effect of pulp capping agents against $\mathrm{S}$. mutans $\mathrm{L}$. acidophilus $\mathrm{E}$. faecalis bacteria, which is involved in the formation and development mechanism of caries, will contribute to the preservation of pulp vitality.

\section{KEYWORDS}

Pulp capping agents, Antibacterial effect, Disk diffusion canal

Vital pulp treatment is a treatment that aims to preserve the pulp that has been damaged due to deep caries, trauma or restorative procedures but has not lost its vitality and to maintain the vitality of the pulp. Covering the remineralizable decalcified dentin tissue with a biocompatible material and stimulating tertiary dentin

\section{ÖZ}

Pulpa Kaplama Materyallerinin Antibakteriyel Etkilerinin Karşılaştırılması

Amaç: Bu çalışmanın amacı, altı farklı pulpa kaplama materyalinin, farklı zaman dilimlerinde Streptococcus mutans, Lactobacillus acidophilus ve Enterococcus faecalis bakterileri üzerindeki antibakteriyel etkilerini değerlendirmektir.

Gereç ve Yöntemler: Çalışmamızda TheraCal LC (BISCO Inc., ABD) Dycal (Dentsply Tulsa Dental, ABD) Biodentine (Septodont, Fransa) Calcimol LC (Voco GmbH, Almanya) Activa (Pulpdent Corporation, ABD) ve MTA Angelus (Angelus.Brazil) materyallerinin antibakteriyel etkileri, disk difüzyon yöntemi ile $S$. mutans (ATCC 25175) L. acidophilus (RSKK 03037) ve E. faecalis (ATCC 29212) suşları kullanılarak değerlendirildi. Materyallerin her biri, üreticinin önerileri doğrultusunda önceden hazırlanmış standart $5 \mathrm{~mm}$ çapında içi bos steril disklerde sertleştirildi. Disklerden çıkarılan materyaller steril numune kaplarına yerleştirildi. Numune kaplarına konulan malzemeler UV ışık cihazı altında 20 dakika süreyle dezenfekte edilerek, $2.5-3 \mathrm{~cm}$ aralıklarla inokule edilen ve homojen olarak dağıtılan çalışma izolatlarını içeren petri kaplarına yerleştirildi. Aynı işlemler 10 ayrı petri kabında her bir mikroorganizma için tekrarlandı. 24-48 saat $37^{\circ} \mathrm{C}$ de inkübasyona bırakılan disklerin etrafındaki inhibisyon zon çapları milimetre olarak ölçüldü. Verilerin istatistiksel analizi, tek yönlü varyans analizi (One Way ANOVA), Kolmogorov-Smirnow Levene testleri ve Bonferroni testleri kullanılarak yapıldı.

Bulgular: Calışmanın sonunda, test edilen materyaller, kullanılan tüm bakteri suşları üzerinde istatistiksel olarak anlamlı bir antibakteriyel etki gösterdi ( $p<0.05$ ). MTA Angelus materyali, diğer pulpa kaplama materyalleri ile karşılaştııılığında her üç bakteri grubu üzerinde en yüksek etkiyi göstermiştir. Calsimol LC ajanı L. acidophilus üzerinde en büyük etkiyi gösterirken, çalışmada kullanılan diğer ajanlar en büyük etkiyi $\mathrm{S}$. mutans üzerinde göstermiştir. Çalışmada kullanılan tüm pulpa kaplama materyallerinin antibakteriyel etkisi 48 . saat sonunda 24 . saat sonuna göre daha yüksek bulundu ancak istatistiksel olarak anlamlı bir fark yoktu $(p>0.05)$.

Sonuç: Çürüklerin oluşum ve gelişme mekanizmasında yer alan $\mathrm{S}$. mutans, L. acidophilus, E. faecalis bakterilerine karşı pulpa kaplama ajanlarının antibakteriyel etkili göstermesinin pulpa canlılığının korunmasına katkı sağlayacağını düşünmekteyiz.

\section{ANAHTAR KELIMELER}

Antibakteriyel etki, Disk difüzyon yöntemi, Pulpa kaplama ajanları

production are frequently performed treatment procedures in dentistry in asymptomatic teeth with the risk of pulp exposure during the removal of caries. ${ }^{1-3}$

It is stated that vital pulp treatments can be applied to reversible or partially inflamed teeth. Careful evaluation of the pulp condition is extremely important in the

${ }^{\alpha}$ Dicle University Faculty of Dentistry, Department of Restorative Dentistry Diyarbakir, Turkey 
success of the treatment. ${ }^{4}$ Sensitivity and pain tests and radiographic diagnosis can be a good indicator of the condition of the pulp. In vital pulp treatments, an adequate blood supply and a healthy periodontium are required to maintain the viability of the pulp. In addition, bleeding control, following disinfection protocols and covering with an appropriate pulp capping agent are other success criteria. ${ }^{5}$

Caries occur as a result of degradation of the dental biofilm layer by acidogenic and aciduric bacteria. Therefore, by reducing the number of bacteria and their activities, it is expected to restore ecological and metabolic balance, promote remineralization and stop the progression of the carious lesion. ${ }^{6}$

Streptococcus mutans, Lactobacillus acidophilus and Enterococcus faecalis bacteria are blamed for tooth decay. Streptococcus mutans, which are frequently observed in the oral flora, are shown as the main factor in the onset of tooth decay. ${ }^{7,8}$ The high number of decayed teeth is explained by the fact that it is acidogenic and aciduric. ${ }^{9}$ Lactobacillus acidophilus, which ferment sugars into lactic acid, are gram positive bacteria. Although these bacteria are detected in quite a large number of patients with active tooth decay, they are not solely responsible for the onset of decay since they are not among the first colonized bacteria. However, it is shown as the main factor in the progression of caries. ${ }^{10,11}$ Enterococcus faecalis, a facultative anaerobe, are gram $(+)$ streptococci. Enterococcus faecalis are bacteria frequently observed in the secondary infection of endodontically treated teeth. ${ }^{12}$

In vital pulp treatments, it is aimed to prevent the progression of caries and the re-activation of the caries left in the cavity. First of all, the relationship between decay and oral environment should be cut. Then, the infected dentin tissue should be removed and the number of microorganisms should be reduced. Finally, caries progression should be prevented with biocompatible and kariostatic filling material. ${ }^{13}$

Various pulp capping agents are preferred in these treatments. The Dycal pulp capping agent used in our study is calcium hydroxide material used as a protective lining under restorative dental materials, cements and other base materials, as well as used directly and indirectly in filling the canal. It has advantages such as providing radiopacity, fast and easy mixing, resistance to acids and stimulation of secondary dentin formation. ${ }^{14}$

TheraCal LC light-cured, resin-modified calcium silicate filler liner; it has been developed as a protective base material under the composite, amalgam and cements with direct and indirect pulp capping. It consists of a mineral part containing calcium oxide, calcium silicate, strontium, silica, barium sulfate and barium zirconate, and a resin part containing Bis-GMA and polydimethacrylate. TheraCal LC provides significant calcium release. TheraCal LC acts as an insulating / barrier and protector for the pulp complex. ${ }^{15}$

The powder structure of the Biodentin material, which is our other pulp capping agent used in the study, consists of tricalcium silicate, dicalcium silicate, calcium oxide, calcium carbonate and zirconium oxide providing radiopacity. Tricalcium silicate is the main ingredient, dicalcium silicate is the second main ingredient. It is a biocompatible and bioactive material used in dentin destruction. It provides superior sealing by completely replacing dentine in both crown and root. ${ }^{16}$

Calcimol LC is a light-curing, radiopaque, onecomponent material. It contains urethane dimethacrylate resin, calcium dihydroxide and TEGDMA. It can be used as a base under indirect pulp capping and all filling materials. ${ }^{17}$

Activa material contains zirconia, CAD/CAM, lithium disilicate and glass ceramic particles. It forms mineral apatite crystals at the tooth interface and acts as a barrier against microleakage, which is the main cause of secondary caries. ${ }^{18}$

MTA Angelus, main components; tricalcium silicate, tricalcium aluminate, tricalcium oxide and silicate oxide. It is indicated in cases of root canal lateral and furcation perforation, internal resorption, retrograde canal filling, pulp covering, and pulpotomy for incomplete teeth. ${ }^{19}$

Many different study methods are used in studies where antibacterial effects are evaluated. Although disc and pit agar diffusion methods, E-Test and dilution tests, automated and molecular studies are among the methods used, disk diffusion method is often preferred because of its low cost, ease of application and the opportunity to compare more than one material at the same time. ${ }^{20}$

The aim of this study is to evaluate the antibacterial activities of six different pulp coating agents (TheraCal LC, Dycal, Biodentine, Calcimol LC, Activa, MTA Angelus) against $S$. mutans, L. acidophilus and $E$. faecalis bacterial strains that are effective in caries formation mechanism.

\section{MATERIALS AND METHODS}

Pulp Capping Agents Used in the Study

Table 1.

\section{Materials tested for antibacterial activities in the study}

\begin{tabular}{|c|c|c|}
\hline Product Trade Name & Manufacturer & Lot Number \\
\hline TheraCal LC & BISCO Inc., USA & 1900000716 \\
\hline Dycal & Dentsply Tulsa Dental, USA & 27425 \\
\hline Biodentine & Septodont, France & B22596 \\
\hline Calcimol LC & Voco GmbH, Germany & 1848310 \\
\hline Activa & Pulpdent Corporation, USA & 180530 \\
\hline MTA Angelus & Angelus, Brazil & 43956 \\
\hline
\end{tabular}




\section{Supply and Preparation of Microorganisms}

Our study was carried out in Ankara University Faculty of Medicine, Department of Microbiology. The microorganisms used were obtained from Ankara Refik Saydam Hygiene Center. In this study, standard, lyophilized, E. faecalis (ATCC 29212), S. mutans (ATCC 25175), L. acidophilus (RSKK 03037) strains were homogenized with $5 \mathrm{ml}$ physiological salt solution (PSS). It was inoculated in BHI (Brain-Heart Infusion) broth for $\mathrm{E}$. faecalis and $\mathrm{S}$. mutans strains, and MRS Broth (Man, Ragosa \& Sharpe) for L. acidophilus strain. It was left to incubate for 24-48 hours in an oven (Heraeus, Germany) with $\mathrm{CO} 2$ at $37^{\circ} \mathrm{C}$. After 48 hours, the bacteria whose growth was controlled by Gram stain were passaged on BHI agar and MRS agar solid media. Then, it was kept in an oven with $\mathrm{CO} 2$ at $37^{\circ} \mathrm{C}$ for 24 hours. After the incubation, bacterial colonies that were found to be grown at sufficient levels were taken with sterile swabs and bacterial suspensions were prepared in 3 $\mathrm{ml}$ PSS and $0.5 \mathrm{McF}$ arland turbidity (1.5x108 CFU / $\mathrm{ml}$ ). $100 \mu \mathrm{l}$ of bacteria suspension from these solutions mixed with Vortex device (Biosan SIA, Latvia) was spread on all surfaces of BHIA (BrainHeart Infusion Agar) and MRS broth agar solid plates with sterile swabs.

\section{Preparation of Samples}

Standard hollow Teflon molds with a diameter of 5 $\mathrm{mm}$ and a height of $2 \mathrm{~mm}$ were used in our study. The pulp capping materials of TheraCal LC, Dycal, Biodentine, Calcimol LC, Activa and MTA Angelus were placed into the hollow Teflon molds individually and hardened in accordance with the manufacturer's recommendations. The materials were placed on petri dishes where microorganisms were cultivated at 2.5-3 cm intervals. The same procedures were repeated for each microorganism in 10 separate petri dishes. After the procedures were completed, it was kept in an oven with $5 \% \mathrm{CO} 2$ for $24-48$ hours at $37^{\circ} \mathrm{C}$ to reproduce the bacteria in the plaques.

\section{Measuring Zone Diameters}

The plates taken out of the oven were checked for reproduction. The diameter of inhibition around the discs was evaluated at 24 and 48 hours by measuring with a millimeter inhibition zone scale. Measurements were made from the two outermost points of the inhibition ring formed around the disc. In order to evaluate the results effectively, inhibition zone diameters in millimeters were recorded by 2 different physicians.

\section{Statistical Analysis}

In this study, mean and standard deviation were given as descriptive statistics, and the conformity of continuous variables to the assumption of normality distribution was evaluated by Kolmogorov-Smirnow
Test and homogeneity by Levene Tests. One-way analysis of variance (One Way ANOVA), which is one of the parametric analysis tests, was used to compare the differences between the means of independent groups, and the Bonferroni Test for multiple comparisons between groups. 0.05 was used as the significance level while interpreting the results; it was stated that there is a significant difference when $p<0.05$, and there is no significant difference if $p>0.05$.

\section{RESULTS}

In our study, it was aimed to compare the antibacterial efficacy of six different pulp capping agents using disk diffusion method at 24 and 48 hours. The placement scheme of the pulp capping agents used in the study and the expansions of the abbreviations are shown in Figure 1.

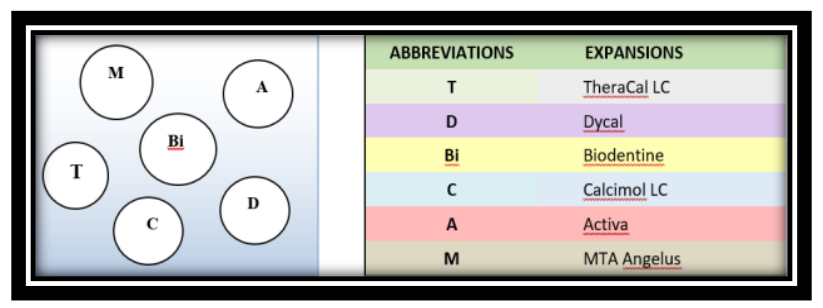

Figure 1

Placement scheme of pulp capping agents and explanation of abbreviations

The pulp capping materials used in the study, TheraCal LC, Dycal, Biodentine, Calcimol LC, Activa and MTA Angelus, were found to be significantly effective for all three bacteria. The average and standard deviation values of the inhibition zone diameters of the pulp capping agents at 24 and 48 hours are shown in Table 2.

Table 2.

Average and standard deviation values of inhibition zone diameters of pulp capping materials at 24 and 48 hours $(n=10)$

\begin{tabular}{|c|c|c|c|c|c|c|c|}
\hline & & $\begin{array}{l}\text { TheraCal } \\
\text { LC }\end{array}$ & Dycal & Biodentine & $\begin{array}{l}\text { Calcimol } \\
\text { LC }\end{array}$ & Activa & $\begin{array}{c}\text { MTA } \\
\text { Angelus }\end{array}$ \\
\hline & & $\begin{array}{c}\text { (Mean } \pm \\
\text { SD) }\end{array}$ & $\begin{array}{c}\text { (Mean } \pm \\
\text { SD) }\end{array}$ & $\begin{array}{c}\text { (Mean } \pm \\
\text { SD) }\end{array}$ & $\begin{array}{l}\text { (Mean } \pm \\
\text { SD) }\end{array}$ & $\begin{array}{c}\text { (Mean } \pm \\
\text { SD) }\end{array}$ & $\begin{array}{l}\text { (Mean } \pm \\
\text { SD) }\end{array}$ \\
\hline \multirow{2}{*}{ S. mutans } & $\begin{array}{c}24 \\
\text { hours }\end{array}$ & $\begin{array}{c}9,70 \pm \\
0,423\end{array}$ & $\begin{array}{c}9 \pm \\
0,558\end{array}$ & $\begin{array}{r}7,30 \pm \\
0,153\end{array}$ & $\begin{array}{r}6,20 \pm \\
0,133\end{array}$ & $\begin{array}{c}6,80 \pm \\
0,389\end{array}$ & $\begin{array}{c}10,50 \pm \\
0,342\end{array}$ \\
\hline & $\begin{array}{c}48 \\
\text { hours }\end{array}$ & $\begin{array}{c}9,80 \pm \\
0,389\end{array}$ & $\begin{array}{c}9,10 \pm \\
0,526\end{array}$ & $\begin{array}{c}7,40 \pm \\
0,163\end{array}$ & $\begin{array}{l}6,30 \pm \\
0,153\end{array}$ & $\begin{array}{c}6,90 \pm \\
0,379\end{array}$ & $\begin{array}{c}10,60 \pm \\
0,371\end{array}$ \\
\hline \multirow{2}{*}{$\begin{array}{c}\text { L. } \\
\text { acidophilus }\end{array}$} & $\begin{array}{c}24 \\
\text { hours }\end{array}$ & $\begin{array}{r}8,80 \pm \\
0,327\end{array}$ & $\begin{array}{r}7,80 \pm \\
0,359\end{array}$ & $\begin{array}{c}6,70 \pm \\
0,213\end{array}$ & $\begin{array}{r}6,50 \pm \\
0,167\end{array}$ & $\begin{array}{c}6,40 \pm \\
0,163\end{array}$ & $\begin{array}{c}9,80 \pm \\
0,200\end{array}$ \\
\hline & $\begin{array}{c}48 \\
\text { hours }\end{array}$ & $\begin{array}{c}8,90 \pm \\
0,348\end{array}$ & $\begin{array}{r}7,90 \pm \\
0,379\end{array}$ & $\begin{array}{c}6,80 \pm \\
0,200\end{array}$ & $\begin{array}{c}6,60 \pm \\
0,163\end{array}$ & $\begin{array}{r}6,50 \pm \\
0,167\end{array}$ & $\begin{array}{c}9,90 \pm \\
0,233\end{array}$ \\
\hline \multirow{2}{*}{ E. faecalis } & $\begin{array}{c}24 \\
\text { hours }\end{array}$ & $\begin{array}{c}8,50 \pm \\
0,401\end{array}$ & $\begin{array}{r}7,60 \pm \\
0,306\end{array}$ & $\begin{array}{c}6,60 \pm \\
0,221\end{array}$ & $\begin{array}{c}6,20 \pm \\
0,133\end{array}$ & $\begin{array}{c}6,10 \pm \\
0,100\end{array}$ & $\begin{array}{c}9,40 \pm \\
0,221\end{array}$ \\
\hline & 48 & $\begin{array}{c}8,60 \pm \\
0.400\end{array}$ & $\begin{array}{c}7,70 \pm \\
0.335\end{array}$ & $\begin{array}{c}6,70 \pm \\
0,260\end{array}$ & $\begin{array}{c}6,30 \pm \\
0,153\end{array}$ & $\begin{array}{c}6,20 \pm \\
0,133\end{array}$ & $\begin{array}{c}9,50 \pm \\
0,224\end{array}$ \\
\hline
\end{tabular}

It was observed that the size of the zone diameter formed by the materials applied on Streptococcus mutans bacteria at 24 and 48 hours were respectively MTA Angelus, TheraCal LC, Dycal, 


\section{Biodentine, Activa and Calcimol.}

It was observed that the size of the zone diameter formed by the materials applied on Lactobacillus acidophilus and Enterococcus faecalis bacteria at 24 and 48 hours were respectively MTA Angelus, TheraCal LC, Dycal, Biodentine, Calcimol and Activa.

The inhibition zone diameters of the pulp capping materials used in the study on S. mutans, L. acidophilus and $\mathrm{E}$. faecalis bacteria strains at the 24th hour are shown in Figure 2, and the inhibition zone diameters they formed at the 48th hour are shown in Figure 3.

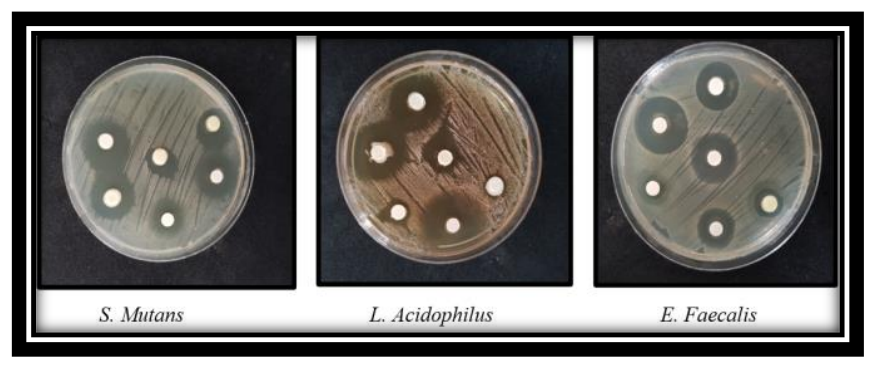

Figure 2

Inhibition zone diameters formed by the materials used in the 24th hour

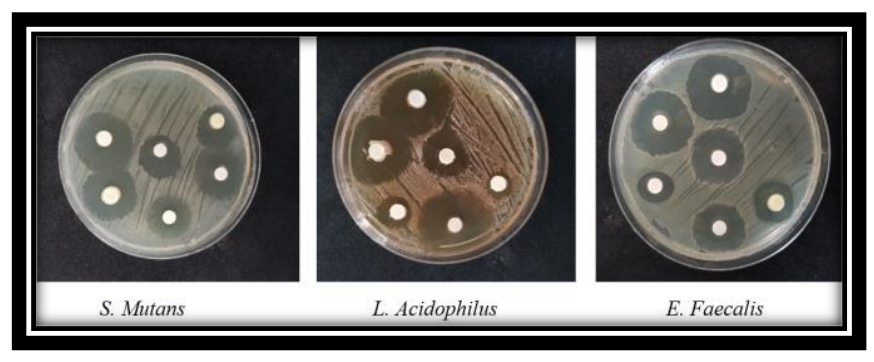

Figure 3

Inhibition zone diameters formed by the materials used at the 48th hour

Comparison of Antibacterial Activities of Pulp Capping Agents According to Different Time Sections

When the antibacterial effects of pulp capping agents on S. Mutans were examined, it was seen that all agents were significantly effective. In paired comparisons, no statistically significant difference was found when TheraCal LC was compared with Dycal $(p>0.05)$ and MTA Angelus $(p>0.05)$ at the end of 24th and 48th hours. When Biodentine was compared with Calcimol LC $(p>0.05)$ and Activa $(p>0.05)$ at the end of 24th and 48th hours, there was no statistically significant difference. However, a statistically significant difference was found with other pulp capping agents $(p<0.05)$.

When the antibacterial effects on L. acidophilus and $\mathrm{E}$. faecalis were examined, it was observed that all pulp capping agents were significantly effective. In paired comparisons, there was no statistically significant difference when the TheraCal LC was compared with Dycal $(p>0.05)$ and MTA Angelus $(p>0.05)$ at the end of 24th and 48th hours, while the comparison of Dycal agent with MTA Angelus $(p<0.05)$ showed a statistically significant difference. difference was seen. When Biodentine was compared with Calcimol LC $(p>0.05)$ and Activa $(p>0.05)$ at the end of 24th and 48th hours, there was no statistically significant difference. However, a statistically significant difference was found with other pulp capping agents $(p<0.05)$.

Comparison of Antibacterial Activities of the Same Pulp Capping Agent According to Different Time Sections

The effect of all pulp capping agents used in the study on Streptococcus mutans, Lactobacillus acidophilus and Enterococcus faecalis bacteria at the end of the 48th hour was found to be more than the effect they exhibited at the end of the 24th hour. However, when the time periods were compared statistically, no significant difference was found $(p>0.05)$.

Comparison of Antibacterial Activities of Pulp Capping Agents Applied in the Same Time Period According to Different Bacteria

The applied TheraCal LC, Dycal, Biodentine, Activa and MTA Angelus were found to have the greatest effect on Streptococcus mutans bacteria both at 24th and 48th hours. It was observed that Lactobacillus acidophilus and Enterococcus faecalis followed respectively. Calcimol LC material showed the greatest effect on Streptococcus mutans bacteria both at 24th and 48th hours, while its effectiveness was observed on Enterococcus faecalis and Lactobacillus acidophilus bacteria, respectively.

\section{DISCUSSION}

Microorganisms are considered as primary etiological factors in endodontic and restorative diseases. Protecting pulp with a correct and effective pulp capping material is very important for the continuation of pulpal vitality. ${ }^{21}$ Therefore, Streptococcus mutans, which is considered to initiate enamel caries, Lactobacillus acidophilus, which is responsible for the progression and development of caries, and Enterococcus faecalis bacteria strains, which are the most common bacteria in intra-canal infections, were used in our study.

Pulp can be exposed mechanically during tooth preparation or in traumatic injuries with the formation of caries. In order to maintain the vitality of the exposed pulp and the function of the tooth in the mouth, vital pulp treatments gain importance. Pulp capping treatment, which is the most applied vital pulp treatment procedure, is a form of treatment in which the tissue is covered with therapeutic materials in order to protect the exposed vital pulp tissue against thermal, chemical and harmful stimuli. ${ }^{22}$ The purpose of pulp capping treatment is to maintain the vitality of the tooth in the mouth by facilitating the formation of reparative dentin in order to preserve pulp vitality and health. ${ }^{23}$ 
The frequently preferred pulp capping materials TheraCal LC, Dycal, Biodentine, Calcimol LC, Activa and MTA Angelus were used in our study.

TheraCal LC is a visible light curing resin modified calcium silicate based pulp capping material. It shows good bonding with dentin and resin-containing restorative materials. The release of hydroxyl ions $(\mathrm{OH}-)$ from the material creates an alkaline environment that prevents bacteria from living and reproducing. In addition, it increases the $\mathrm{pH}$ of the environment and causes irritation of the pulp tissue. Superficial necrosis develops on the exposed pulp and mineralization is stimulated against the necrotic area. ${ }^{24,25}$

Dycal is a self-hardening, radiopaque calcium hydroxide based material used in direct and indirect capping treatments. ${ }^{26}$ It is accepted that the antibacterial property of calcium hydroxide is formed by its separation into calcium and hydroxyl ions in an aqueous environment. Hydroxyl ions create an alkaline $\mathrm{pH}$ environment unfavorable for the survival of bacteria in the cavity, causing damage to the bacterial cytoplasmic membrane and bacterial DNA, and denaturation of bacterial proteins. ${ }^{27}$

The high pH of the MTA is attributed to the continuous release of calcium and the formation of calcium hydroxide ${ }^{28,29}$ It is thought that the antibacterial effect of MTA is due to its high $\mathrm{pH}$ value and its ability to diffuse well into the environment. ${ }^{30}$ While MTA has an antibacterial effect against some facultative bacteria, it has been observed that it is ineffective against anaerobic bacteria. It has also been reported to be effective in preventing bacterial leakage. ${ }^{31}$

Calcimol LC, another agent used in the study, is a pulp capping material that releases calcium with light curing resin. In addition to having an antibacterial effect, calcium hydroxide in its structure induces dentin remineralization and alkaline $\mathrm{pH}$ formation. ${ }^{32}$

Biodentine has been developed to improve some properties of MTA such as long hardening time and clinical application difficulty. The $\mathrm{pH}$ value of Biodentine increases up to approximately 12.5 thanks to the calcium hydroxide released during the hardening reaction. Due to this alkaline $\mathrm{pH}$ value, it has been found that it shows antibacterial properties by preventing the growth of microorganisms. ${ }^{33,34}$

Activa material, developed as a combination of the aesthetic and high physical properties of composites, is a bioactive material. Since it contains resin-modified glass ionomer, it can release fluorine and phosphate ions and can be recharged. Changes in calcium and fluoride ions provide a superior antimicrobial activity. ${ }^{35,36}$

Farrugia et al. found in their antimicrobial studies that TheraCal LC showed more antibacterial effects than Biodentine. Erfanparast et al. compared the effectiveness of TheraCal LC and MTA materials in direct pulp capping in their study on primary molar teeth of 46 healthy children aged 5-7 years. After 6 and 12 months of follow-up, TheraCal LC was found close to the MTA material with a $91.8 \%$ success rate. ${ }^{38}$ Poggio et al. in their studies comparing the antibacterial effects of pulp capping agents, they stated that TheraCal LC inhibits mutans more than Biodentine. ${ }^{39}$

Bağış et al. found that Dycal material was more effective on mutans than Calcimol LC in their study, where they examined the antibacterial effects of four different calcium hydroxide-containing pastes. In addition, they stated that the effect seen at the 48th hour was greater than the effect at the 24th hour. The result of this study supports our study. ${ }^{40}$

Fathy et al. in their study examining the antibacterial effect of Biodentine and TheraCal LC materials on Streptococcus mutans, reported that both materials showed antibacterial effects on $\mathrm{S}$. mutans, but Biodentin was more effective ${ }^{41}$

ElReash et al. stated that Activa material showed more antimicrobial effect on Enterococcus faecalis bacteria than Streptococcus mutans in their studies. This suggests that ions released from resin-based materials may affect the antimicrobial potential in direct proportion to the decrease in $\mathrm{pH}$ levels. ${ }^{42}$

Eldeniz et al. in their study examining the antibacterial effects of pulp capping materials, they reported that MTA has more antibacterial effect at the end of the 24th hour compared to other materials. ${ }^{43}$ Hezaimi et al. in their studies investigating the antibacterial effects of graycolored MTA and white-colored MTA on Enterococcus faecalis and Streptococcus sangius bacteria, they reported that the gray-colored MTA had more antibacterial effects on Enterococcus faecalis and that the effect increased in direct proportion to the increase in concentration. ${ }^{44}$ Luczaj et al. evaluated the antibacterial effects of MTA Angelus material on streptococcus species, especially Streptococcus mutans, and it was determined that it showed an antibacterial effect against mutans. ${ }^{45}$ Zarrabi et al., Razmi et al., Donyavi et al. observed that MTA has an antibacterial effect on Enterococcus faecalis and Streptococcus mutans bacteria. ${ }^{46-48}$ Poggio et al. compared the antibacterial effects of six different pulp capping agents against three different types of streptococci. MTA Angelus, Biodentine, Calcimol LC, Calcicur, Dycal and TheraCal LC agents all showed effects on Streptococcus mutans. In the study, it was reported that the material that had the most effect on S. mutans was MTA Angelus, 
followed by TheraCal LC, Dycal, Biodentine, Calcimol and Calcicur, respectively (49). Our study is consistent with the results of other studies.

Disk diffusion method is often preferred in antibacterial research in dentistry. Although inexpensive and ease of application are among the advantages of the method, the type and duration of the effect of the tested agent cannot be determined (50).

\section{CONCLUSIONS}

In our study, it was observed that MTA Angelus material showed high antibacterial activity on S. mutans, L. acidophilus and E. faecalis strains. TheraCal LC and Dycal materials were determined to have antibacterial activity close to the MTA Angelus material. In the light of the studies conducted, it is thought that the use of these pulp capping agents against $S$. mutans, L. acidophilus, E. faecalis bacteria, which are involved in the formation and development mechanism of caries, will be beneficial and in this way, pulp vitality will be preserved. It is also predicted that long-term clinical studies that will be supported by in vivo studies will be beneficial. 


\section{REFERENCES}

1. Hilton TJ. Keys to clinical success with pulp capping: a review of the literatüre. Operative Dentistry. 2009; 34 (5): 615-25.

2. Arandi N. Calcium hydroxide liners: a literature review. Clinical, Cosmetic and Investigational Dentistry. 2017; 9: $67-72$.

3. Stangvaltaite $L$, et al. Management of pulps exposed during carious tissue removal in adults: a multi-national questionnaire-based survey, Clinical Oral Investigations. 2016; 21 (7): 2303-9.

4. Al-Hiyasat AS, Barrieshi-Nusair KM, Al-Omari MA. The radiographic outcomes of direct pulp-capping procedures performed by dental students: a retrospective study. J Am Dent Assoc. 2006;137 (12): 1699-705.

5. Ricketts D. Management of the deep carious lesion and the vital pulp dentine complex. Br Dent J. 2001; 191 (11): 606-10.

6. Ghoddusi J, Forghani M, Parisay I. New Approaches in Vital Pulp Therapy in Permanent Teeth. Iran Endod J 2014; 9: 15-22.

7. Ge Y, Caufield P, Fisch G, Li Y. Streptococcus mutans and Streptococcus sanguinis colonization correlated with caries experience in children. Caries research. 2008; 42: 444-8.

8. Çakır FY, Gürgan S, Atar N. Çürük Mikrobiyolojisi. Hacettepe Diş Hek Fak Derg 2010; 34: 78-91.

9. Gross EL, Beall CJ, Kutsch SR, Firestone ND, Leys EJ, Griffen AL. Beyond Streptococcus mutans: dental caries onset linked to multiple species by $16 \mathrm{~S}$ rRNA community analysis. 2012; 7: e47722.

10.Beighton D. The complex oral microflora of high-risk individuals and groups and its role in the caries process. Community Dent Oral Epidemiol 2005; 33: 248-55.

11. Baysan A, Yalçın Çakır F, Gürgan S, Whiley RA. Reduction in bacteria in infected dentin by antimicrobial bonding agent. J Dent Res. 2009; 88: 91.

12. Lin YH, Mickel AK, Chogle S. Effectiveness of selected materials against Enterococcus faecalis: Part 3. The antibacterial effect of calcium hydroxide and chlorhexidine on Enterococcus faecalis. Journal of endodontics. 2003; 29 (9): 565-6.

13. Mickenautsch S, Yengopal V, Banerjee A. Pulp response to resin-modified glass ionomer and calcium hydroxide cements in deep cavities: A quantitative systematic review. Dent Mater. 2010; 26 (8): 761-70.

14.Gandolfi M. G, Siboni F, Botero T, Bossù M, Riccitiello F, Prati C. Calcium silicate and calcium hydroxide materials for pulp capping: biointeractivity, porosity, solubility and bioactivity of current formulations. J Appl Biomater Funct Mater. 2015; 13 (1): 43-60.
15.H. Bakhtiar, et al. Human pulp responses to partial pulpotomy treatment with TheraCal as compared with biodentine and ProRoot MTA: a clinical trial, Journal of Endodontics, 2017; 43 (11): 1786-91.

16. Katge FA and Patil DP. Comparative analysis of 2 calcium silicate-based cements (biodentine and mineral trioxide aggregate) as direct pulpcapping agent in young permanent molars: a split mouth study, Journal of Endodontics. 2017; 43 (4): 507-13.

17. Fathy S. Remineralization ability of two hydraulic calcium-silicate based dental pulp capping materials: Cell-independent model. J. Clin. Exp. Dent. 2019; 11: 360-6.

18.Porenczuk A, et al. A comparison of the remineralizing potential of dental restorative materials by analyzing their fluoride release profiles. Adv. Clin. Exp. Med. 2019; 28: 815-23.

19. Moussa, SA. Mineral Trioxide Aggregate (MTA) vs. Calcium Hydroxide in Direct Pulp Capping Literature Review. Online J. Dent. Oral Heal. 2018; 1: 1-6.

20. Maalej SM, Meziou MR, Rhimi FM, Hammami A. Comparison of disc diffusion, Etest and agar dilution for susceptibility testing of colistin against Enterobacteriaceae. Letters in Applied Microbiology. 2011; 53 (5): 546-51.

21.Bhavana V, Chaitanya KP, Gandi P, Patil J, Dola $B$, Reddy RB. Evaluation of antibacterial and antifungal activity of new calcium-based cement [Biodentine] compared to MTA and glass ionomer cement. J Conserv Dent. 2015; 18 (1): 44-6.

22.Ghoddusi J, Forghani M, Parisay I. Newvapproaches in vital pulp therapy in permanent teeth. Iran Endod J 2014; 9:15-22.

23. Aguilar $P$, Linsuwanont $P$. Vital pulp therapy in vital permanent teeth with cariously exposed pulp: A systematic review. J Endod. 2011; 37: 581-7.

24.Arandi NZ, Rabi T. TheraCal LC: From Biochemical and Bioactive Properties to Clinical Applications. International Journal of Dentistry Volume 2018; ID 3484653: 6.

25.Poggio C, Lombardini M, Colombo M, Beltrami $\mathrm{R}$, Rindi S. "Solubility and $\mathrm{pH}$ of direct pulp capping materials: a comparative study," Journal of Applied Biomaterials \& Functional Materials. 2015; 13 (2): 73-193.

26. Furey A, Hjelmhaug J, Lobner D. Toxicity of Flow Line, Durafill VS, and Dycal to dental pulp cells: effects of growth factors. J. Endod. 2010; 36 (7): 1149-53. 
27. Qureshi A, Soujanya E, Nandakumar, Pratapkumar Sambashivarao. Recent advances in pulp capping materials: an overview. J Clin Diagn Res 2014; 8: 31621.

28.Islam I, Chng HK, Yap AU. X-ray diffraction analysis of mineral trioxide aggregate and Portland cement. Int Endod J. 2006; 39: 220-5.

29. Fridland M, Rosado R. Mineral trioxide aggregate (MTA) solubility and porosity with different water-topowder ratios. J Endod. 2003; 29: 814-7.

30.Duarte MA, Demarchi AC, Yamashita JC, Kuga MC, Fraga Sde C. pH and calcium ion release of 2 root-end filling materials. Oral Surg Oral Med Oral Pathol Oral Radiol Endod. 2003; 95 (3): 345-7.

31.Zhu L, Yang J, Zhang J, Peng BA comparative study of bioaggregate and proroot $\mathrm{mta}$ on adhesion, migration, and attachment of human dental pulp cells. J Endod. 2014; 40: 1118-23.

32.Zanini M, Sautier JM, Berdal A, Simon S. Biodentine induces immortalized murine pulp cell differentiation into odontoblast-like cells and stimulates biomineralization, Journal of Endodontics. 2012; 38 (9): 1220-6.

33. About I. Biodentine: from biochemical and bioactive properties to clinical applications. Giornale Italiano di Endodonzia. 2016; 30: 81-8.

34.Arora V, Nikhil V, Sharma N, Arora P. Bioactive dentin replacement. J Dent Med Sci. 2013; 12: 51-7.

35.Bostanci B, Gezgin O. The In Vitro Evaluation of Calcium and Bioactive Glass Based Pulp Capping. J Dent Oral Care Med. 2018; 4 (3): 301.

36. Abou ElReash A, Hamama H, Abdo W, Wu Q, Zaen ElDin A, Xiaoli X. Biocompatibility of new bioactive resin composite versus calcium silicate cements: an animal study. BMC Oral Health. 2019; 19 (1): 194.

37.Farrugia, C, Lung, CYK, Schembri Wismayer, P, AriasMoliz, MT \& Camilleri. 'The Relationship of Surface Characteristics and Antimicrobial Performance of Pulp Capping Materials'. Journal of Endodontics. 2018; 44 (7): 1115-20.

38. Erfanparast L, Iranparvar $\mathrm{P}$, Vafaei A. Direct pulp capping in primary molars using a resin-modified Portland cement-based material (TheraCal) compared to MTA with 12-month follow-up: a randomised clinical trial. European Archives of Paediatric Dentistry. 2018; 19: 197-203.

39.Poggio C, Beltrami R, Colombo M, Ceci M, Dagna A, Chiesa M. In vitro antibacterial activity of different pulp capping materials. J Clin Exp Dent. 2015; 7 (5): 584-8.

40.Bağış Y. H, Ertaş E, Mısırlıgil A, Bağış B. Evaluation of Antibacterial Effects of Calcium Hydroxide Liners. A. Ü. Diş Hek. Fak. Derg. 2001; 28 (3): 251-6.

41.Fathy S. M, Abd El-Aziz A. M, Labah D. A. Cellular interaction and antibacterial efficacy of two hydraulic calcium silicate-based cements: Cell-dependent model. J Conserv Dent. 2019; 22 (1): 17-22.
42. ElReash A. A, Hamama $H$, Eldars $W$, Lingwei $G$, El-Din A. M. Z, Xiaoli X. Antimicrobial activity and $\mathrm{pH}$ measurement of calcium silicate cements versus new bioactive resin composite restorative material. BMC Oral Health. 2019; 19: 235.

43. Eldeniz A. U, Hadimli $H$. $H$, Ataoglu $H$, Ørstavik D. "Antibacterial effect of selected root-end filling materials," Journal of Endodontics. 2006; 32 (4): 345-9.

44.Al-Hezaimi K, Al-Shalan T. A, Naghshbandi J, Oglesby S, Simon J. H. S, Rotstein I. "Antibacterial effect of two Mineral Trioxide Aggregate (MTA) preparations against Enterococcus faecalis and Streptococcus sanguis in vitro," Journal of Endodontics. 2006; 32 (11): 1053-6.

45.Luczaj-Cepowicz E, Pawinska M, MarczukKolada G, Leszczynska K, Waszkiel D. Antibacterial activity of two Mineral Trioxide Aggregate materials in vitro evaluation. Ann Acad Med Stetin. 2008; 54 (1):147-50.

46. Hasan Zarrabi $M$, Javidi $M$, Naderinasab $M$, Gharechahi M. Comparative evaluation of antimicrobial activity of three cements: new endodontic cement [NEC], mineral trioxide aggregate [MTA] and Portland. J Oral Sci. 2009; 51 (3): 437-42.

47. Razmi H, Aminsobhani M, Bolhari B, Shamshirgar F, Shahsavan S, Shamshiri AR. Calcium Enriched Mixture and Mineral Trioxide Aggregate Activities against Enterococcus Faecalis in Presence of Dentin. Iran Endod J. 2013; 8 (4):191-6.

48.Donyavi Z, Heidari N, Khoshbin E, Shahriari S, Farhadian $M$, Yousefi Mashouf $R$, et al. Antibacterial activity of mineral trioxide aggregate, new endodontic cement, Retro MTA and Ortho MTA against common endodontic pathogens. IAJPS. 2017; 4 (12): 4720-8.

49.Poggio C, Arciola CR, Beltrami R, Monaco A, Dagna A, Lombardini $M$, et al. Cytocompatibility and antibacterial properties of capping materials. Scientific World Journal. 2014; ID 181945: 10.

50.Imazato S, Kuramoto A, Takahashi Y, Ebisu S, Peters MC, In vitro antibacterial effects of the dentin primer of Clearfil Protect Bond. Dent Mater. 2006; 22: 527-32.

\section{Corresponding Author:}

\section{Elif PInar BAKIR}

Dicle University Faculty of Dentistry

Department of Restorative Dentistry,

Diyarbakır, Turkey

Phone : +904122411017

E-mail : elifpinarbakir@gmail.com 